\title{
Implication of Landscape Changes Using Google Earth Historical Imagery in Yenagoa Bayelsa State, Nigeria
}

\section{Abaye Ebinyo Oreikio}

Department of Geology, Niger Delta University, Wilberforce Island, Bayelsa State, Nigeria Email: desmondeteh@gmail.com

\section{Ayowei Alvin Harry}

University of Salford, London UK

Email: ayoweialvin@gmail.com

Akajiaku Ugochukwu Charles

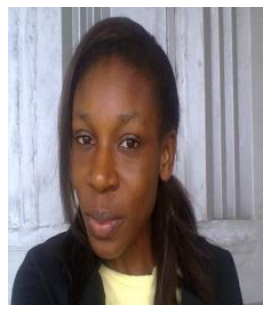

University of Port Harcourt, Rivers State, Nigeria

Email: akajiakuflowz@gmail.com

\section{Eteh Desmond Rowland}

Department of Geology, Niger Delta University, Wilberforce Island, Bayelsa State, Nigeria

Email: desmondeteh@gmail.com

\section{How to Cite}

Abaye, Ebinyo. Oreikio. Ayowei, Alvin. Harry. Akajiaku, Ugochukwu. Charles. Eteh, Desmond. Rowland. (2022). Implication of Landscape Changes Using Google Earth Historical Imagery in Yenagoa Bayelsa State, Nigeria. Sumerianz Journal of Scientific Research, Vol. 5, No. 1, pp. 20-31.

\author{
Article History \\ Received: 5 January 2022 \\ Revised: 12 February 2022 \\ Accepted: 14 February 2022 \\ Published: 18 February 2022
}

\begin{abstract}
Assessment and impact on the environment of dumpsites investigated between 1990 and 2015 and 2015 to 2020 in Yenagoa, Bayelsa State, Nigeria, using Remote Sensing and Geographical Information Systems (GIS) are used to evaluate landscape change from Google Earth Historical Imagery (GIS). Historical Google Earth imagery shows an increase from 1900 to 2015, and again from 2015 to 2020, due to an increase in built-up areas, which resulted in illegal dumpsites in the environment, implying an increase in population due to migration and industrial activities in the area. Six soil samples were collected from illegal dumpsites and one from a control location and analysed for heavy metal ions. The $\mathrm{Fe}, \mathrm{Mn}, \mathrm{Cr}, \mathrm{Cu}, \mathrm{Zn}, \mathrm{Ni}, \mathrm{Cd}$, and $\mathrm{Pb}$ concentrations were determined using the atomic absorption spectrometer. All of the illegal dumpsites were discovered to be located along the market area, close to Epie Creek and the pound. Furthermore, the pollution load index (PLI) and contamination factor (CF) results show that heavy metal pollution is present in the area. As a result, it is recommended that urban growth be tracked in order to plan ahead of time for various dumpsite locations, and that site suitability studies for landfill selection sites be made available using GIS and remote sensing-based Multi-Criteria Evaluation. Combining remote sensing and GIS, according to the study, could be an effective approach to landscape planning and environmental improvement.

Keywords: GIS and remote sensing; Landscape; Illegal dumpsite; Heavy metal; Google earth.
\end{abstract}

\section{Introduction}

The Yenagoa local government has been undergoing development due to an increase in population and structural activities, which in turn create changes on the surface of the earth. These occur because of deforestation, disasters, changes in rivers, and urbanization. According to Jabeen, et al. [1], an increase in the population leads to an increase in solid waste generation. Liquid and solid waste discharged into lakes, ponds, or rivers will cause serious problems due to an increase in the population. Jabeen, et al. [1], also states that water is contaminated by human excreta. In contaminated water and soil, there are a large number of bacteria that are harmful to human 
health. Due to the increasing number of people, the government is incapable of supplying essential needs to citizens. There is a lack of environmental law in the area [2]. Polythene bags and plastic waste are a major source of pollution. Heavy metals are widely highlighted as potential risks and occurrences in polluted soils in the literature [3]. It is estimated that three-quarters of the people in urban areas defecate in the open. $77 \%$ of people are using flush latrines and $8 \%$ are using pit latrines. According to Kamble [4], urbanization can cause many infectious diseases, including overcrowding, unhygienic conditions, and unsafe drinking water, which are major health issues in urban areas. Pesticides are used to kill bacteria, pests, and different germs. Chemicals containing pesticides are directly polluting the water and affect the quality of the water. If pesticides were excessive in amount or poorly managed, then they would be hazardous to the agricultural ecosystem [5]. Only $60 \%$ of fertilizers are used on the soil. Other chemicals leached into the soil pollute the water. Cyanobacteria thrive in polluted water and excess phosphate runoff leads to eutrophication. Therefore, if change detection occurs on the activities of the earth's surface and is done timely and accurately, then the link and interaction between natural phenomena and humans may be best analysed and understood as a result. Better management and use of resources may be achieved as a result of that. Change detection involves the application of multi-temporal datasets to quantitatively analyse the changes in land cover classes. Change detection may be done in ancient ways or by applying remote sensing technologies. The traditional methods are expensive, time-consuming, and not very accurate, whereas all of these problems do not exist with remote sensing technology. Remote sensing (RS) data has been one of the most important data sources for studies of landuse spatial and temporal changes. Multi-temporal RS datasets are opportunely processed and elaborated, allowing us to map and identify landscape changes, giving an effective effort to sustainable landscape planning and management [6]. In particular, utilizing the integration of RS and GIS techniques, it is possible to analyse and classify the changing pattern of landuse during a long period and, as a result, understand the changes within the area of interest. GIS techniques are efficiently exploited to analyse the effects of various factors on landuse changes; those factors include population density, terrain slope, proximity to roads, and surrounding land use. The availability of a time-series dataset is essential to understand and monitor the urban expansion process and to characterise and locate the evolution trends at a detailed level. In fact, during the last three decades, satellite time series such as Landsat images have been exploited in several studies Masek, et al. [7] and Yang and Lo [8]. It is well known that the development of urban areas can transform landscapes formed by rural lifestyles into urban ones and bring functional changes from a morphological and structural point of view [8]. Moreover, the population outside central cities has grown faster than downtown areas in many developed regions, demonstrating a certain tendency for the outward expansion of urban areas [9]. According to Google Earth Features [10], it provides access to sub-meter pixel resolution data for nearly a quarter of the world's territory and three-quarters of the world's population. Highresolution Google Earth data can be used to validate datasets previously used for urban extent [11] and land cover. While Google Earth has the potential to be more widely used in scientific publications, particularly in LULC analyses [12], one significant difficulty is that Google Earth's native analysis functions are limited to point and polygon [13]. The objective of this research is to investigate how populations increase and lead to illegal dumpsites, how these dumpsites affect human health due to the wrong location of various markets in the area, and finally, to understand urban migration patterns in the area using Google Earth historical imagery.

\section{Materials and Methods}

\subsection{Location and Geology of the Study Area}

The Yenagoa which is the capital city of Bayelsa State and is among the developed city in Nigeria. The area under instigation covers a mass land of an area of $410.61 \mathrm{~km}^{2}$ and the population estimated to be about 1704,515 by the National Population Commission [14]. It is found in the Southern part of Nigeria and with a good road network that links to various parts of the State such as LGA like Kolokuma/Opokuma, Sagbama, Southern Ijaw, Ogbia, etc. This area lies within longitudes $006^{\circ} 177^{\prime} 30^{\prime}$ and $006^{\circ} 21^{\prime} 30^{\prime \prime}$ East oand Latitudes $04^{\circ} 55^{\prime} 0^{\prime \prime}$ and $04^{0}$ 7'30" North within the coastal area of the recent Niger Delta (Figure. 1). 


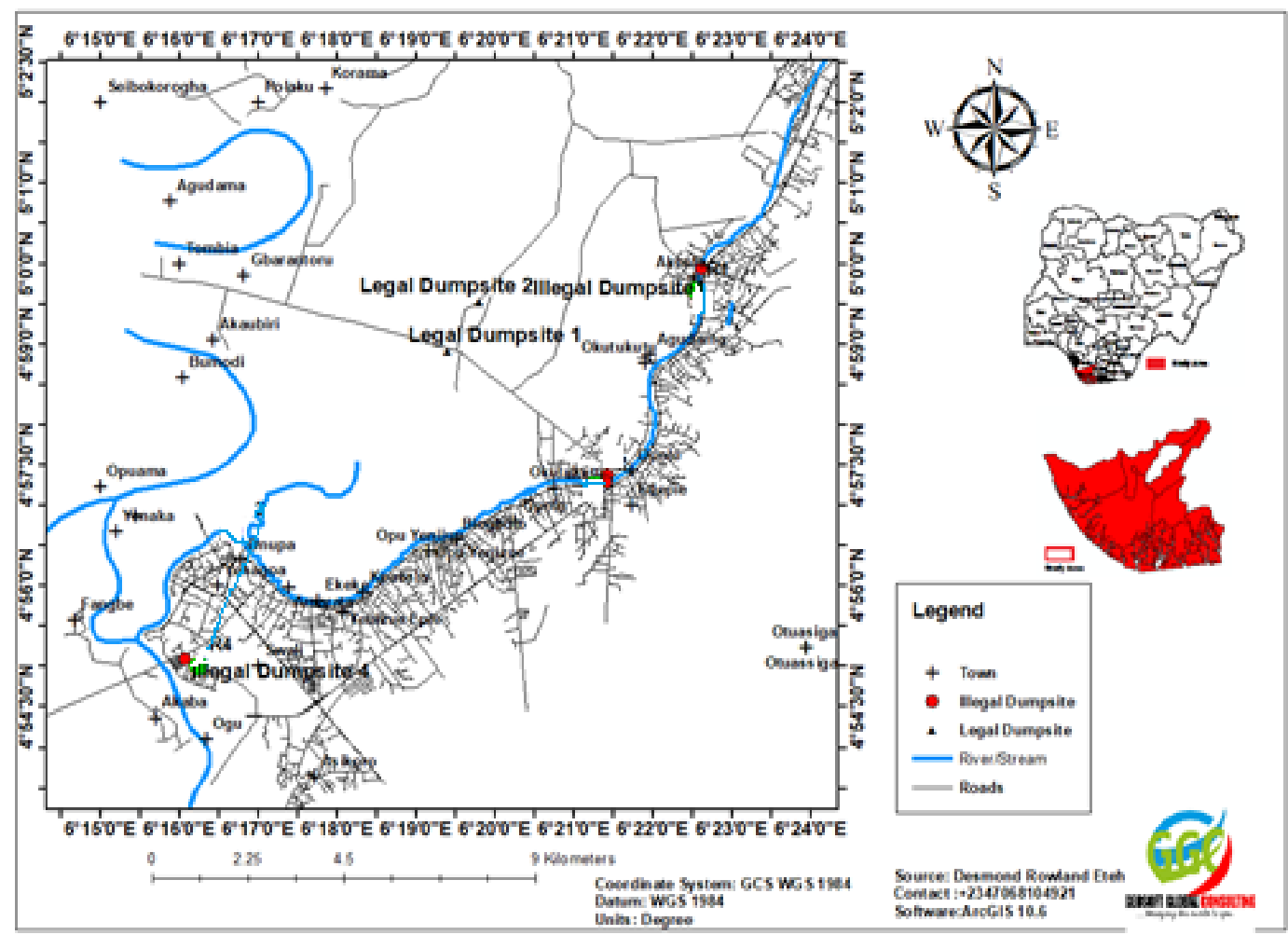

Figure-1. Study location map

\section{Data Collection}

\subsection{Remote Sensing Data Collection}

The historical satellite imagery is access from Google earth in 1990, 2015 and 2020 with the aid of universal map downloader.

Table-1. List of Satellite Imagery collected

\begin{tabular}{l|l|l|l}
\hline Satellite & Date & Spatial Resolution $(\mathbf{m})$ & Source \\
\hline Google Earth Imagery & $14 / 12 / 1990$ & $3 \mathrm{~m}$ & {$[15]$} \\
\hline Google Earth Imagery & $02 / 03 / 2020$ & $3 \mathrm{~m}$ & {$[15]$} \\
\hline Google Earth Imagery & $06 / 02 / 2020$ & $3 \mathrm{~m}$ & {$[15]$} \\
\hline
\end{tabular}

\subsection{Soil Sampling Data Collection}

A total of seven (7) soil samples were collected using a hand auger, and they are found in various legal and illegal dumps across the entire study area in Figure. 1, except that which is taken for control (C1) in Table 3. Soil samples were taken from the outer surface at a depth of 0-1 $\mathrm{m}$, with a total of 2-3 kg of soil per sample according to the Guide to Sampling Techniques. They are stored in a polyethylene bag for transport and then analysed in the laboratory.

\subsection{Limitation}

Cloud cover in the Niger Delta region did not allow good access to Goole earth historical imagery from 1995 to 2010

\subsection{Data Analysis}

The following heavy metal ions: $\mathrm{Fe}, \mathrm{Mn}, \mathrm{Cr}, \mathrm{Cu}, \mathrm{Zn}, \mathrm{Ni}, \mathrm{Cd}$, and $\mathrm{Pb}$, were analysed using the atomic absorption spectrometer. The samples were digested with acid in the hood and filtered. The samples were then filtered and diluted to $100 \mathrm{~mL}$ in a $100 \mathrm{~mL}$ vial. They were then taken for analysis on the AAS spectrometer.

\subsection{Data Processing}

The data was collected in degrees, minutes, and seconds using a portable global positioning system (GPS) and imported into Microsoft Excel, where it was converted to decimal degrees and transferred to a geographic information system environment in the format of a database. The political boundaries and roads were digitized before producing a location map using ArcGIS software.

\section{Results and Discussion}

The result in Table 2 from landscape changes from Google Earth shows that in 1990 the built-up area was 5.5 $\mathrm{km}^{2}$, indicating $4 \%$, in 2015 it was $48.53 \mathrm{~km}^{2}$, showing 39\%, and in 2020 the built-up area was $72.1 \mathrm{~km}^{2}$, implying 57\%. The result also reveals a low population in 1990 (Figure 2 and 5), a slightly higher population in 2015 (Figure 


\section{Sumerianz Journal of Scientific Research}

3 and 5) and a high population in 2020 (Figure 4 and 5), implying that as the region tends to develop and more and more industries continue to migrate and as more roads are built, we can see that the development of urban growth lends to the increase in population and also plays a negative role in water and soil pollution.

Table-2. Analysis of Landuse changes from Google Earth Imagery

\begin{tabular}{l|l|l|l}
\hline \multicolumn{4}{|c}{ Table-2. Analysis of Landuse changes from Google Earth Imagery } \\
\hline S/N & Goole Earth Imagery & Area $\left.\mathbf{( k m}^{\mathbf{2}}\right)$ & Percentage $\mathbf{( \% )}$ \\
\hline 1 & 1990 & 5.5 & 4 \\
\hline 2 & 2015 & 48.53 & 39 \\
\hline 3 & 2020 & 72.1 & 57 \\
\hline
\end{tabular}

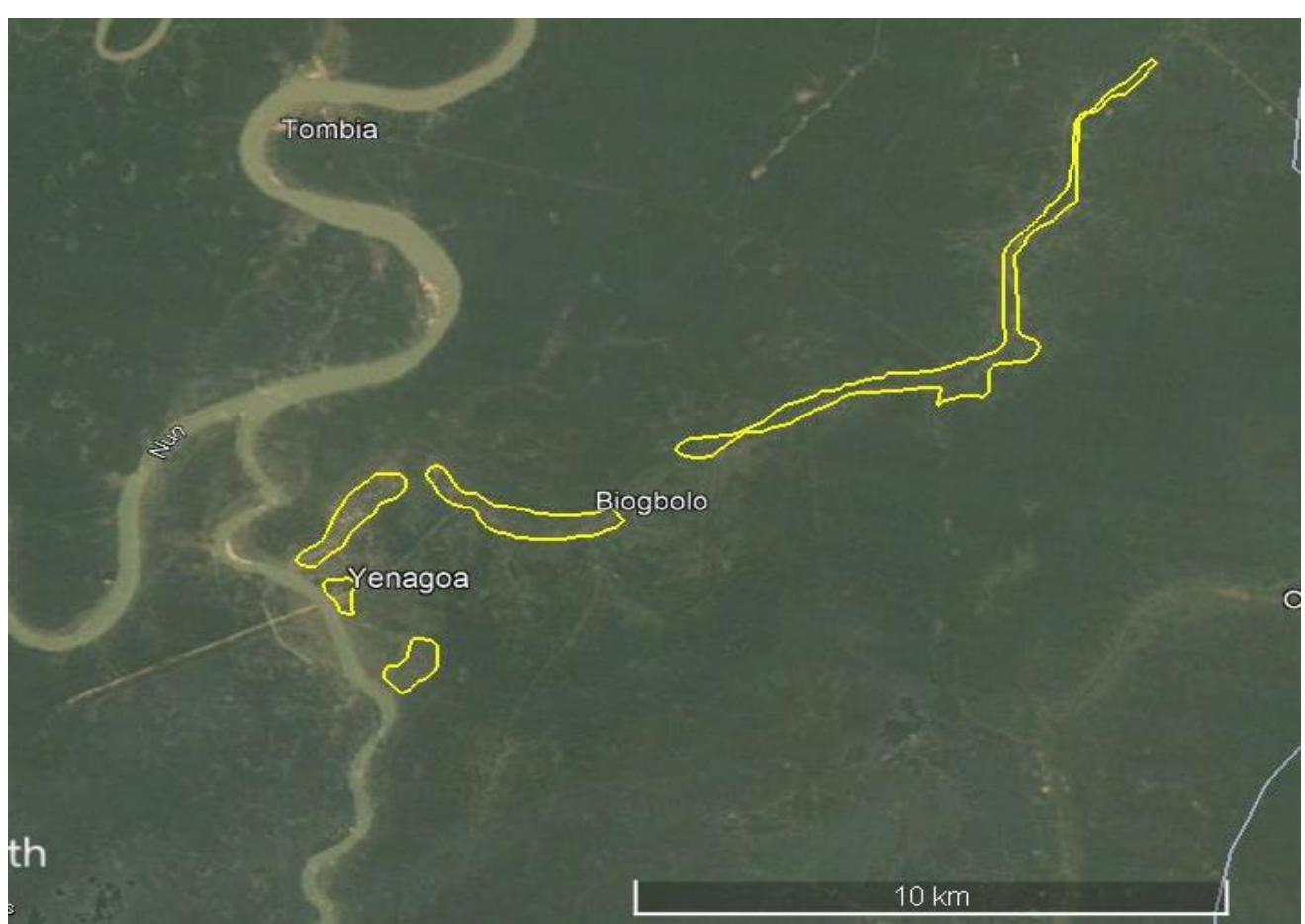

Figure-2. Goole Earth image of 1990

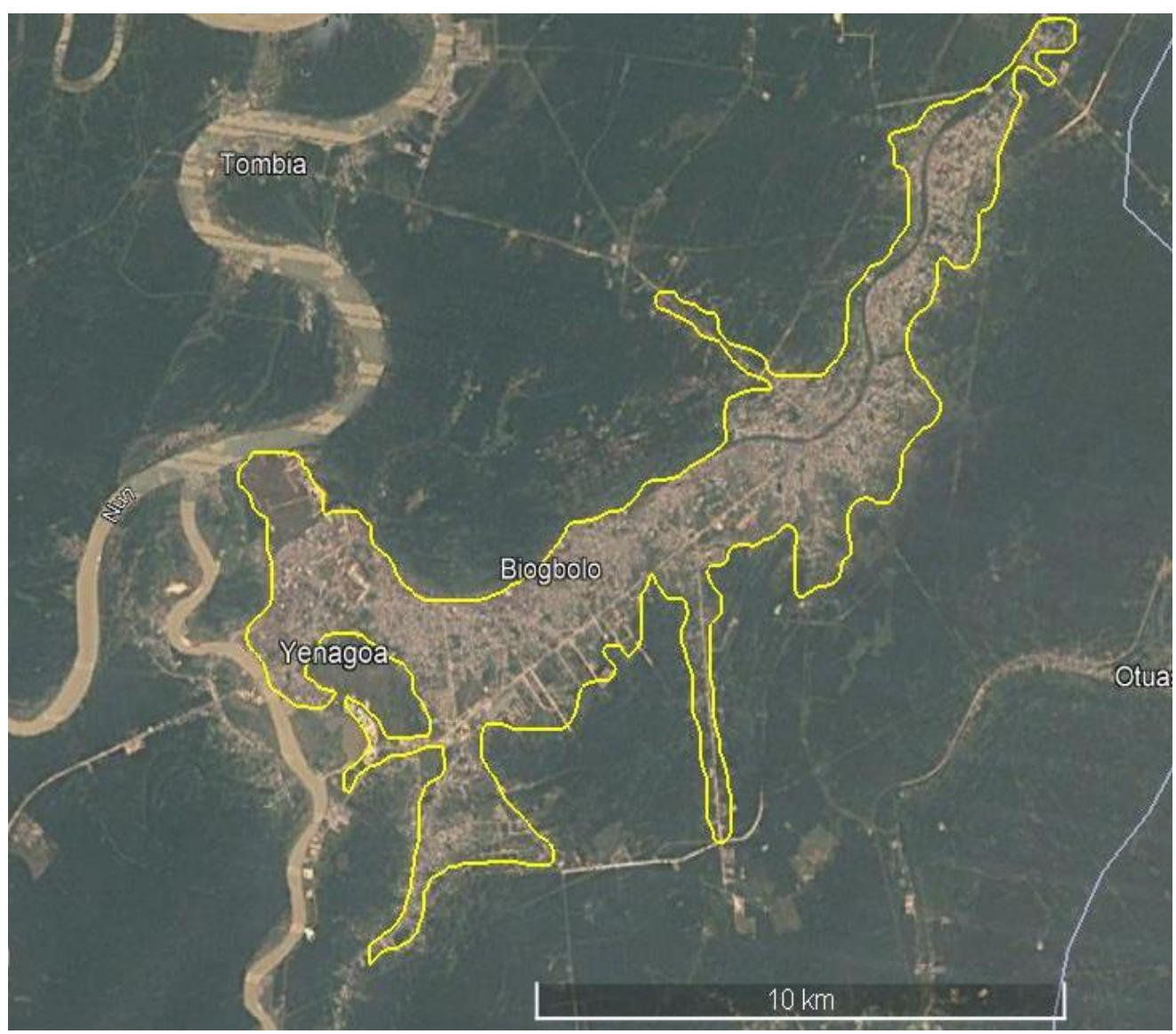

Figure-3. Goole Earth image of 2015 


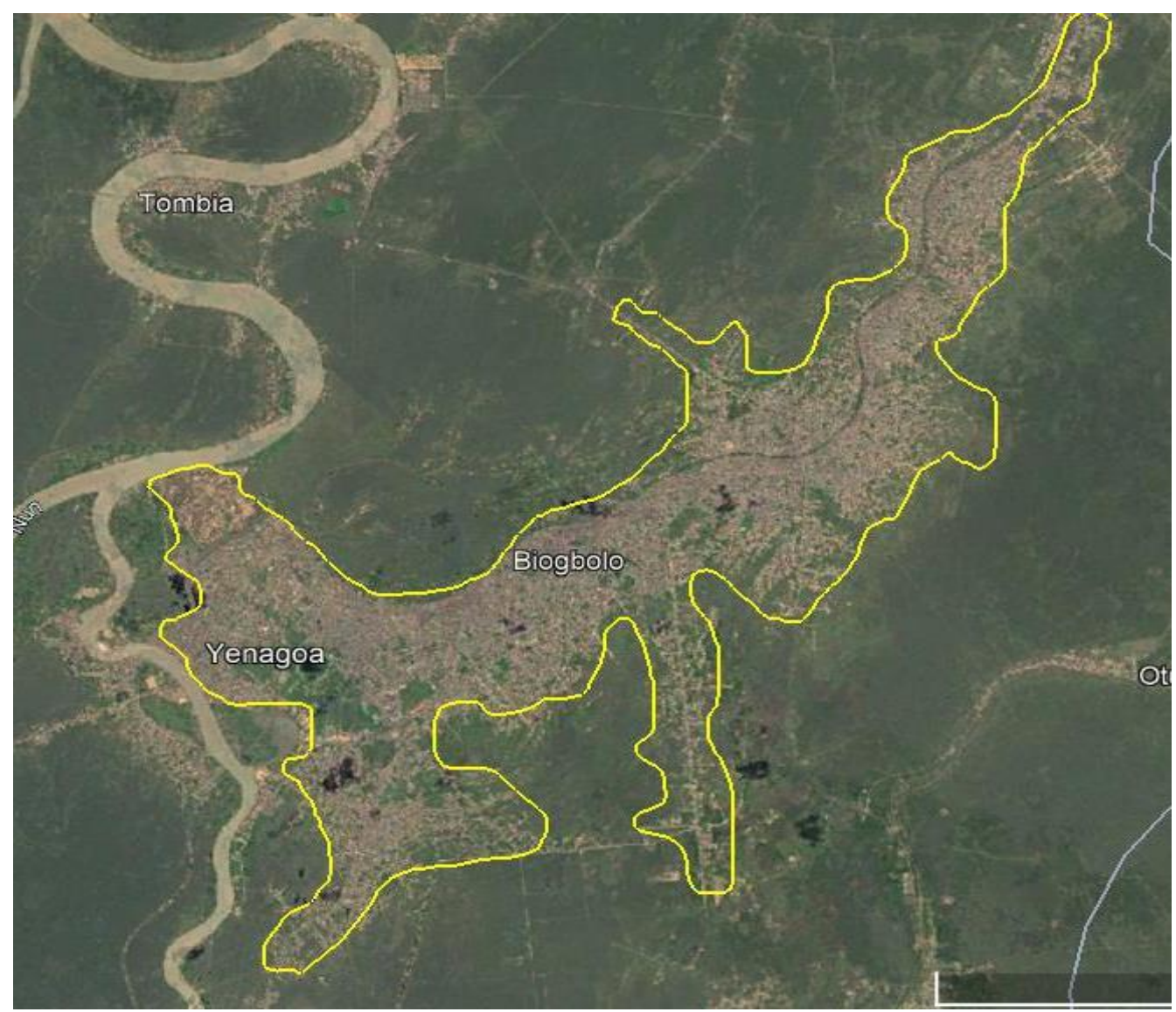

Figure-4. Goole Earth image of 2020

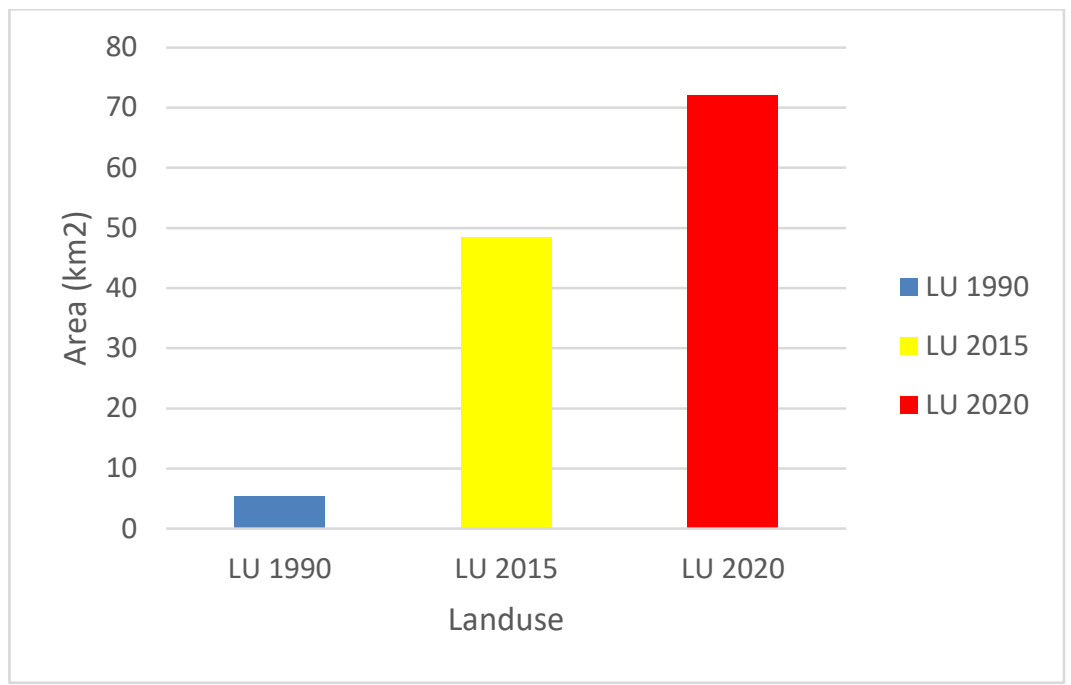

Figure-5. Area of Landuse change from Google Earth imagery

\section{Percentage of Landuse changes}

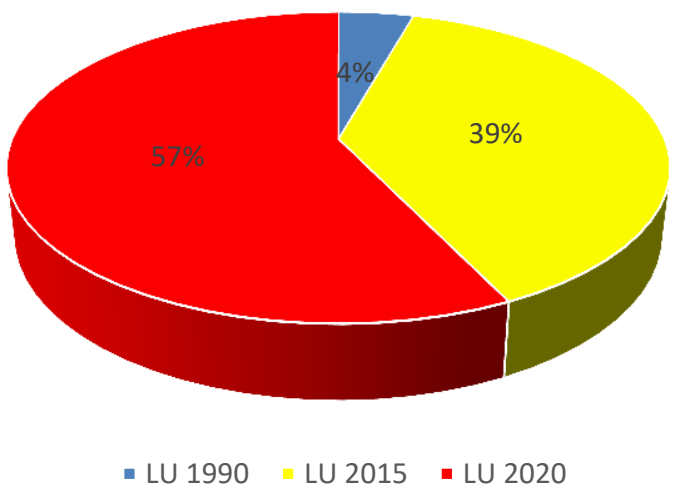

Figure-6. Percentage of landuse changes from Google Earth imagery 
Sumerianz Journal of Scientific Research

Table-3. Descriptive Statistics for heavy metals in soil

\begin{tabular}{l|l|l|l|l|l|l|l|l|l|l}
\hline Sample code & Long & Lat & $\mathrm{Fe}$ & $\mathrm{Mn}$ & $\mathrm{Cu}$ & $\mathrm{Cd}$ & $\mathrm{Cr}$ & $\mathrm{Ni}$ & $\mathrm{Zn}$ & $\mathrm{Pb}$ \\
\hline L1 & 6.37696 & 4.99907 & 97.72 & 23.04 & 7.87 & 4.98 & 8.97 & 2.62 & 10.98 & 5.10 \\
\hline L2 & 6.37696 & 4.99917 & 100.71 & 33.04 & 9.87 & 5.98 & 9.97 & 3.62 & 11.98 & 6.10 \\
\hline L3 & 6.357223 & 4.95617 & 983.29 & 39.33 & 14.25 & 6.76 & 17.19 & 6.22 & 20.87 & 11.10 \\
\hline L4 & 6.357058 & 4.95493 & 932.54 & 39.32 & 14.17 & 9.02 & 15.81 & 6.51 & 20.52 & 10.73 \\
\hline L5 & 6.267906 & 4.91809 & 1807.43 & 1.93 & 10.79 & 10.27 & 39.33 & 2.92 & 4.81 & 10.72 \\
\hline L6 & 6.309784 & 4.93543 & 1686.35 & 2.12 & 11.01 & 10.31 & 44.18 & 2.90 & 5.12 & 22.87 \\
\hline Control (C1) & 6.40897 & 4.92897 & 55.53 & 1.34 & 2.05 & 4.03 & 0.14 & 1.02 & 3.55 & 3.01 \\
\hline
\end{tabular}

\subsection{Contamination Factor (CF) and Pollution Load Index (PLI)}

The contamination and pollution load index were carried out to determine the level of contamination and pollution of the study area. These results are shown in Table 3.

\subsection{Contamination Factor}

The Contamination Factor (CF) of the heavy metals measured was calculated as Lacatusu [16]:

$$
\mathbf{C F}=\frac{C \text { Metal }}{\text { C Background }}
$$

Where $\mathrm{Cm}=$ the measured concentration of metal in the sample and $\mathrm{Cb}$ is the background concentration of the same metal in average shale or any other standard (for this study it is DPR standard). The interpretation of contamination index is based on the following intervals as proposed by Lacatusu [16] CF $=0-1.0$ signifies contamination; 1.1-4.0, slight moderate pollution; 4.1-8.0 Severe pollution; 8.1-16.0 Very severe pollution; >16.0 Extreme pollution.

\subsection{Pollution Load Index}

The pollution load index, proposed by Tomlinson, et al. [17], indicates the contamination detection through the comparison of levels between sites. It is expressed as the concentration factor of each heavy metal, considering its background value: $P L I=\sqrt[n]{C F 1 * C F 2 * C F 3 \ldots .}$

Where $\mathrm{CF}$ is the contamination factor; n, number of metals. The pollution load index can indicate either no pollution $(\mathrm{PLI} \leq 1)$, moderate pollution $(1<\mathrm{PLI} \leq 2)$, heavy pollution $(2<\mathrm{PLI} \leq 3)$, or extremely heavy pollution $(3>\mathrm{PLI})$ [18].

Table-4. Result of pollution load index and Contamination Factor heavy metals in soil

\begin{tabular}{|c|c|c|c|c|c|c|c|c|c|c|}
\hline \multirow{2}{*}{$\begin{array}{l}\text { Sample } \\
\text { Code }\end{array}$} & \multicolumn{8}{|c|}{\begin{tabular}{l|l} 
& Contamination Factor
\end{tabular}} & \multirow[t]{2}{*}{ PLI } & \multirow[t]{2}{*}{ Mean CF } \\
\hline & $\mathrm{Mn}$ & $\mathrm{Cu}$ & $\mathrm{Cd}$ & $\mathrm{Cr}$ & $\mathrm{Ni}$ & $\mathrm{Zn}$ & $\mathrm{Pb}$ & $\mathrm{Fe}$ & & \\
\hline L1 & 1.93 & 17.20 & 3.84 & 1.23 & 2.57 & 2.57 & 3.09 & 1.76 & 2.95 & 4.28 \\
\hline $\mathrm{L} 2$ & 1.99 & 24.66 & 4.82 & 1.48 & 3.55 & 3.55 & 3.38 & 1.81 & 3.58 & 5.66 \\
\hline L3 & 19.46 & 29.35 & 6.95 & 1.68 & 6.10 & 6.10 & 5.88 & 17.71 & 8.44 & 11.65 \\
\hline L4 & 18.46 & 29.35 & 6.91 & 2.24 & 6.38 & 6.38 & 5.78 & 16.79 & 8.71 & 11.54 \\
\hline L5 & 35.77 & 1.44 & 5.26 & 2.55 & 2.86 & 2.86 & 1.36 & 32.55 & 4.73 & 10.58 \\
\hline L6 & 33.37 & 1.58 & 5.37 & 2.56 & 2.84 & 2.84 & 1.44 & 30.37 & 4.74 & 10.05 \\
\hline
\end{tabular}

The results obtained from Table 3 and 4 indicate that the pollution load index (PLI) indicates to L1 that the soil has heavy pollution, while L2, L3, L4, L5 and L6 indicate that the soil has extremely heavy pollution. The results of the contamination factor $(\mathrm{CF})$ indicate that the soil contains from slight pollution to moderate to extreme pollution, which is as a result of industrial and solid waste. These chemicals are fatal to living organisms, and many vegetables and fruits are contaminated with these chemicals by Kamble [4] and Ebenstein [19]. Heavy rains and floods are linked to extreme weather conditions and create different diseases for developed countries and those in development [20]. $10 \%$ of the population depends on food and vegetables grown in contaminated water [21]. Many water-borne infectious diseases are linked to faecal pollution of water sources and lead to faecal-oral infection [15]. The health risk associated with polluted water includes different diseases such as respiratory diseases, cancer, diarrheal diseases, neurological disorders, and cardiovascular diseases [22]. The cancer death rate is higher in rural areas than in urban areas as city dwellers use treated water for drinking, while rural dwellers do not have access to treated water and use water. untreated [1].

The result from Figure 7a of historical Google Earth imagery along Tombia road in 1990 indicates that legal landfills 1 and 2 are not present, resulting in a low population; from Figure 7b in 2015, the legal landfill 1 is present along the road but the legal landfill 2 is not present, implying a gradual growth in the population; and from Figure 7c in 2020, the legal landfill 2 is present but the landfill Legal 1 is not present, implying a gradual increase in the population.

Figures 8a and 9a, the result of historical Google Earth imagery in 1990 in the Etegwe and Akenfa markets, clearly show that illegal dumping is not present owing to the reduced population. However, Figures $8 \mathrm{~b}, 8 \mathrm{c}$, and $9 \mathrm{~b}$, $9 \mathrm{c}$ in 2015 and 2020 identify that illegal dumping is present in the market place, which is predominantly polluted during the rainy season, when rain water flows into the Epic Creek, which serves as a source of drinking water. 


\section{Sumerianz Journal of Scientific Research}

Figure 10a shows that the illegal dump is not present because the area was underpopulated in 1990. However, in 2015 and 2020, in Figure 10b and 10c, there is an illegal dump, implying the area is developed, resulting in the illegal dump being present in the market, polluting the area and causing runoff water to flow into the Ikoli river and pond, which serve as a source of water for domestic use, causing disease.

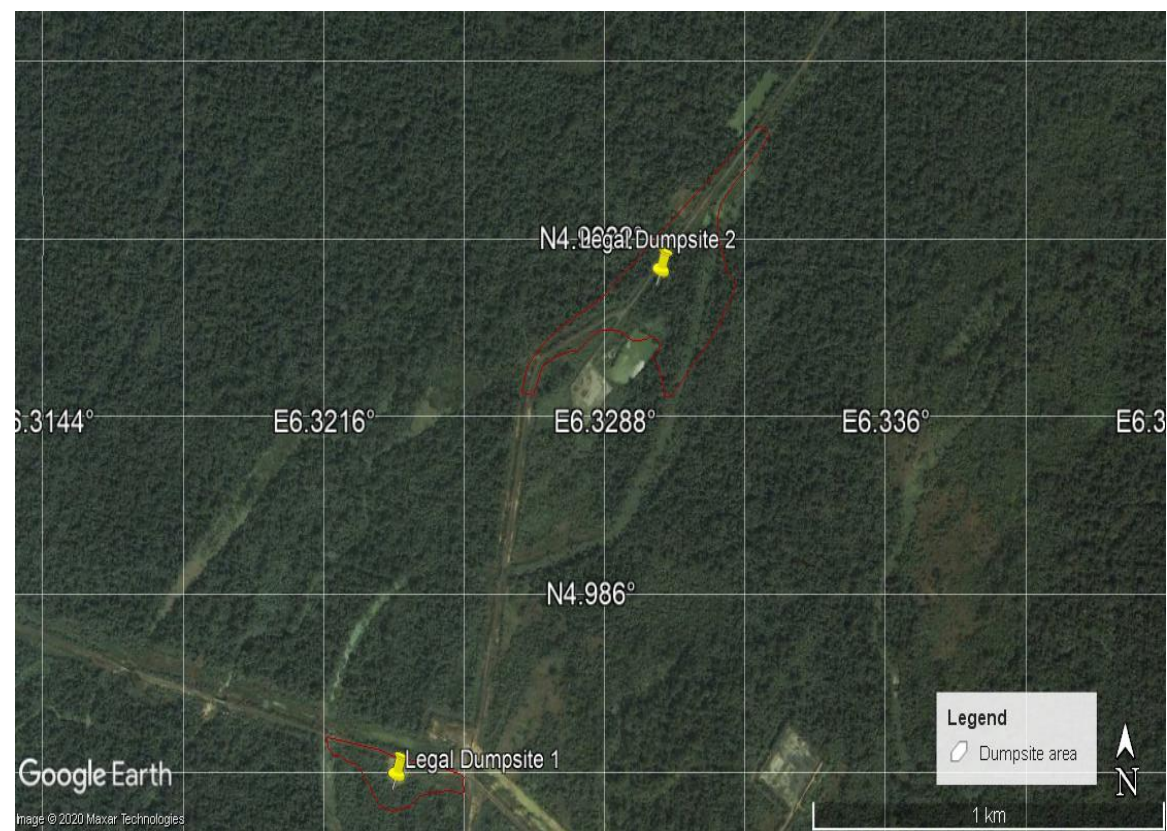

Figure-7a. Google map of 1990 in Tombia road Showing legal Dumpsite 1 and 2 not present

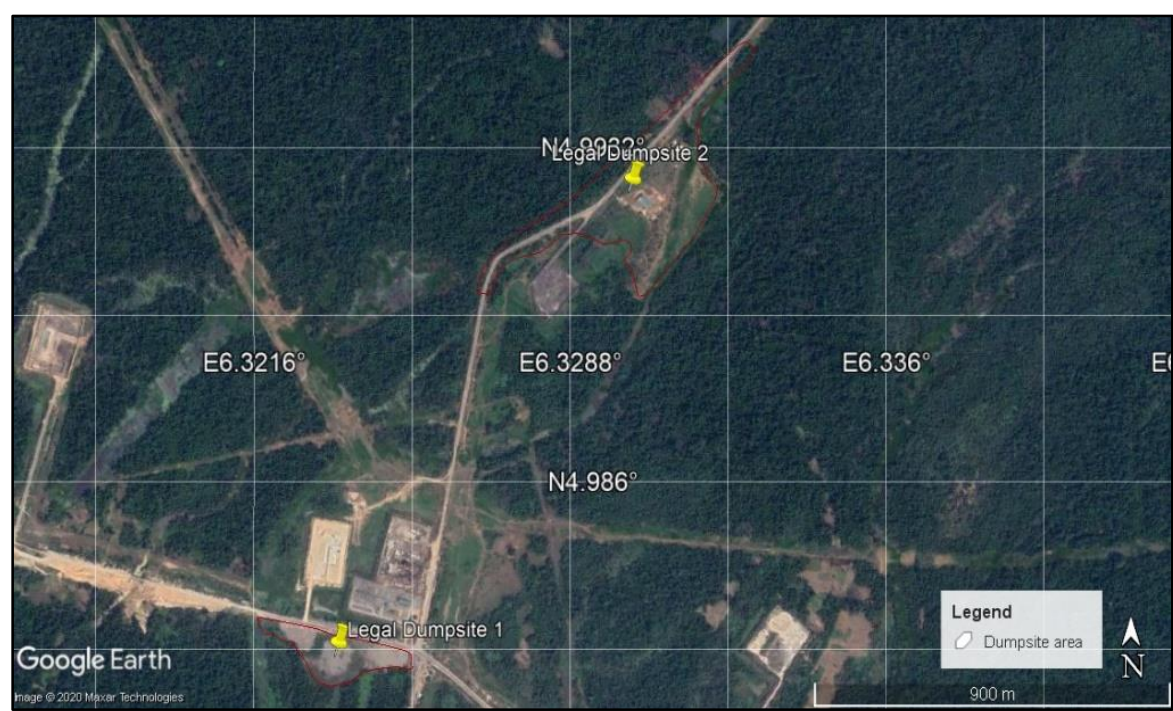

Figure-7b. Google map of 2015 in Tombia road showing legal dumpsite 1 present but not present in legal dumpsite 2

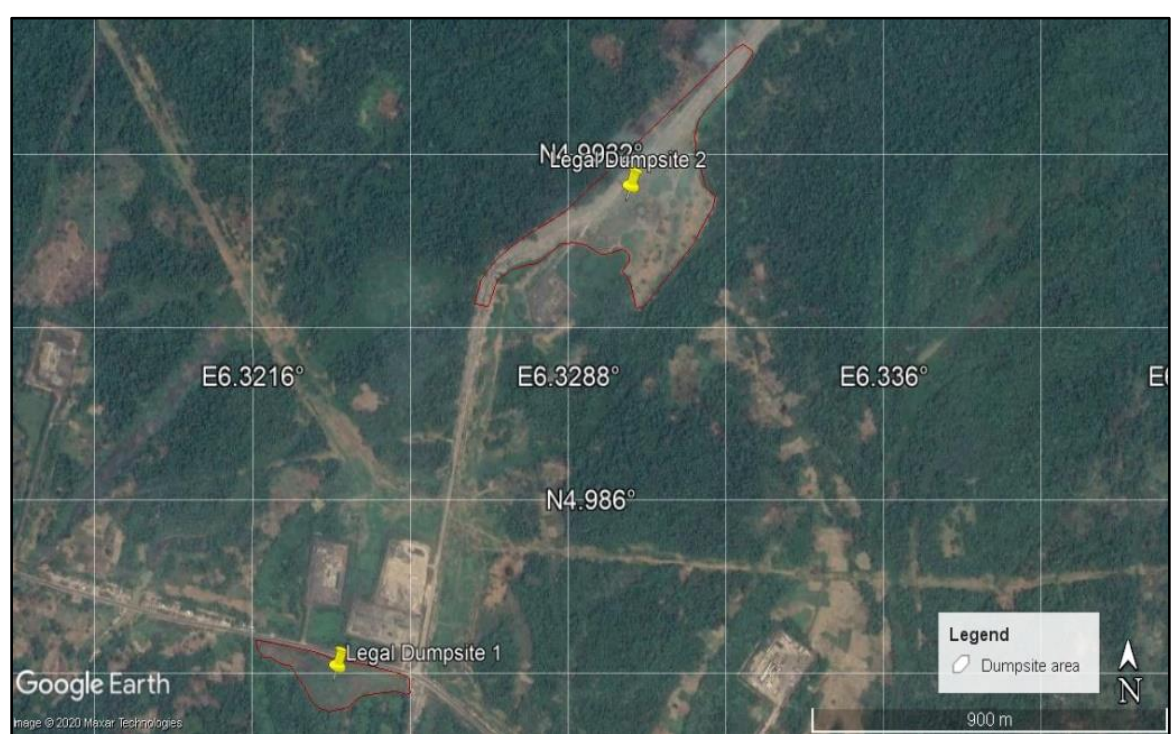

Figure-7c. Google map of 2020 in Tombia road Showing legal dumpsite 2 present but not present in legal dumpsite 1 
Sumerianz Journal of Scientific Research

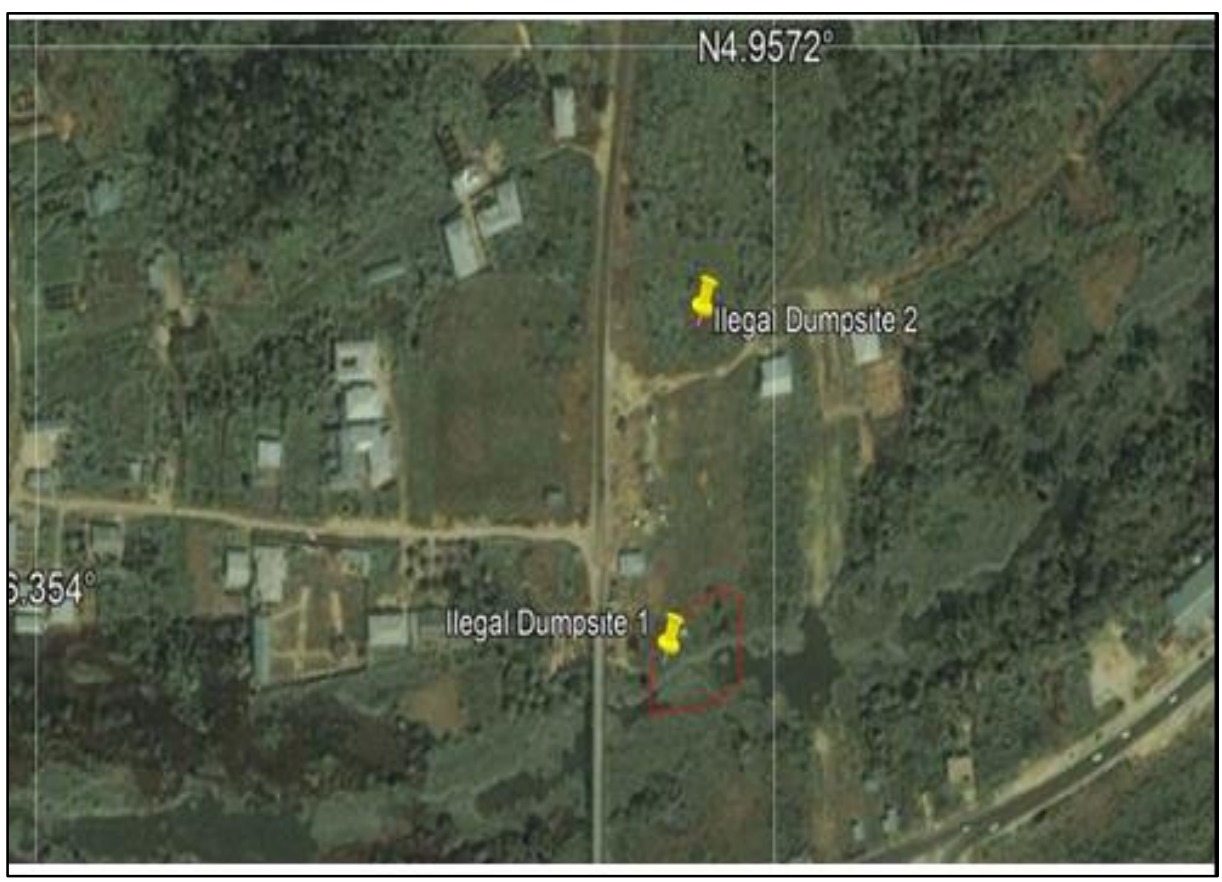

Figure-8a. Google map of 1990 in Etegwe market showing illegal Dumpsite 1 and 2 not present

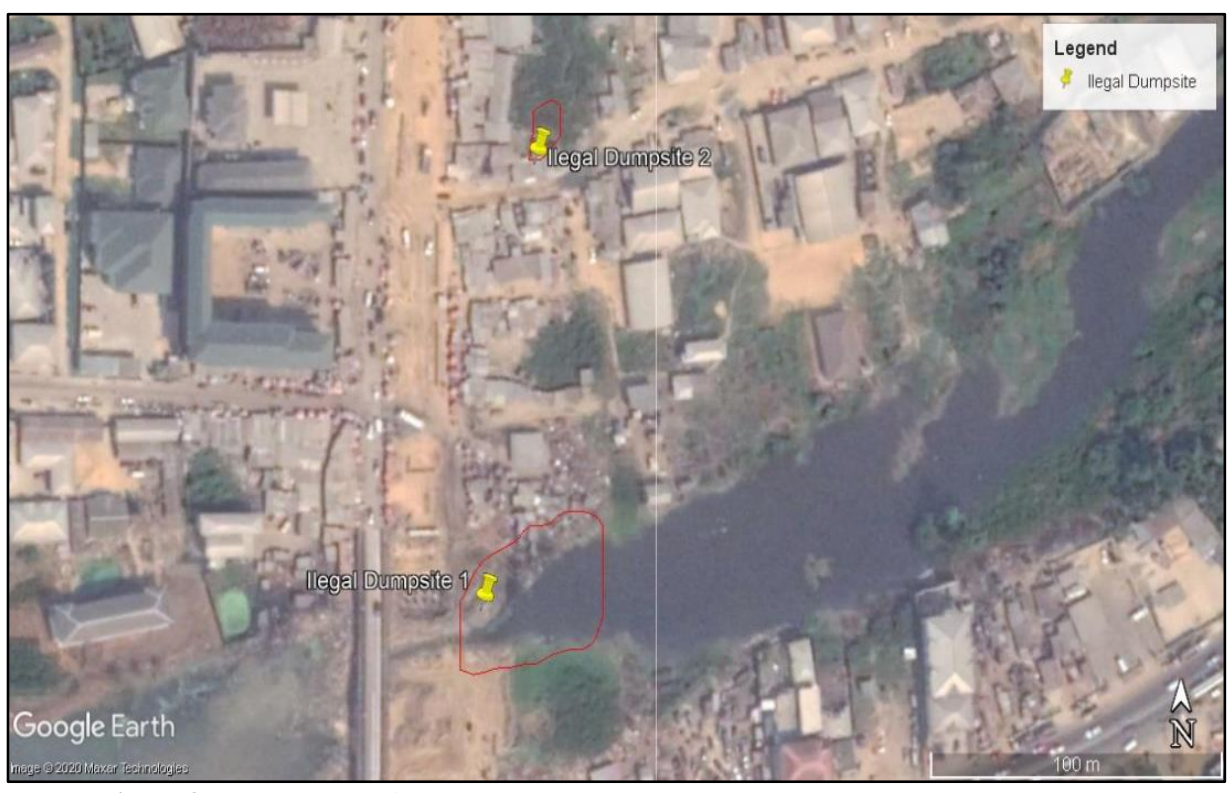

Figure-8b. Google map of 2015 in Etegwe market, showing illegal dumpsite 1 and 2 present

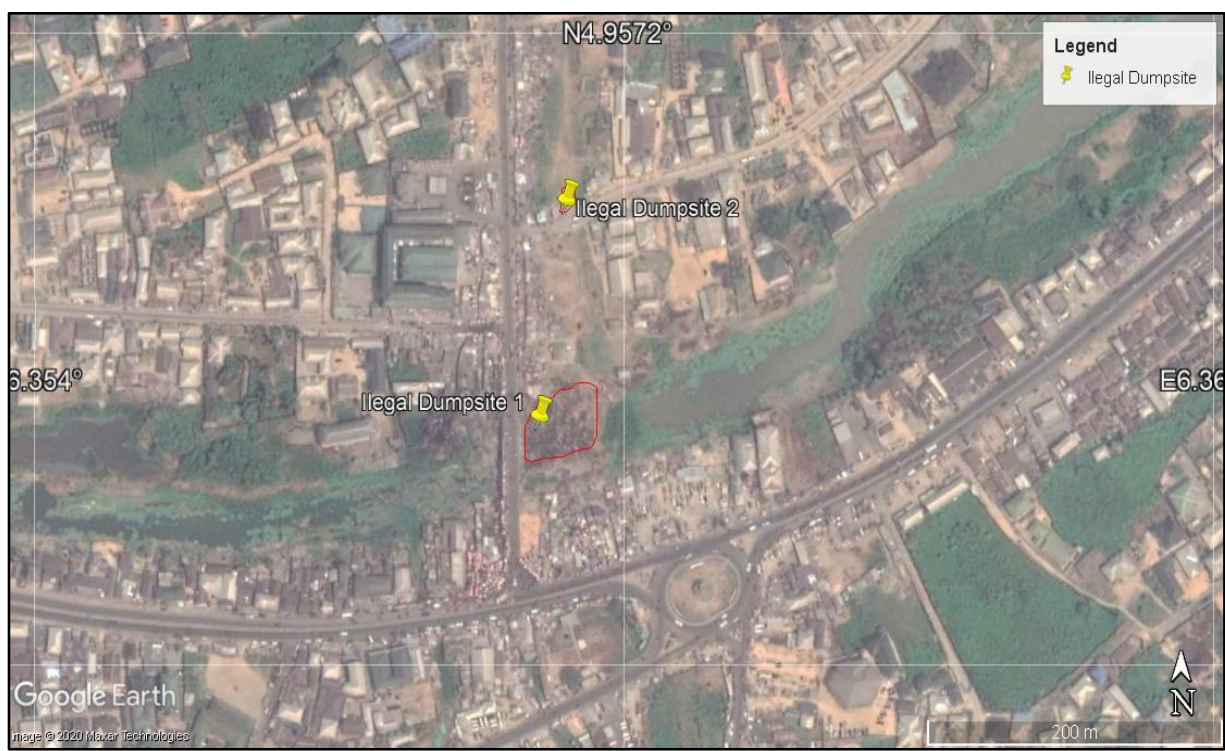

Figure-8c. Google map of 2020 in Etegwe, market showing illegal dumpsite 1and 2 presents 


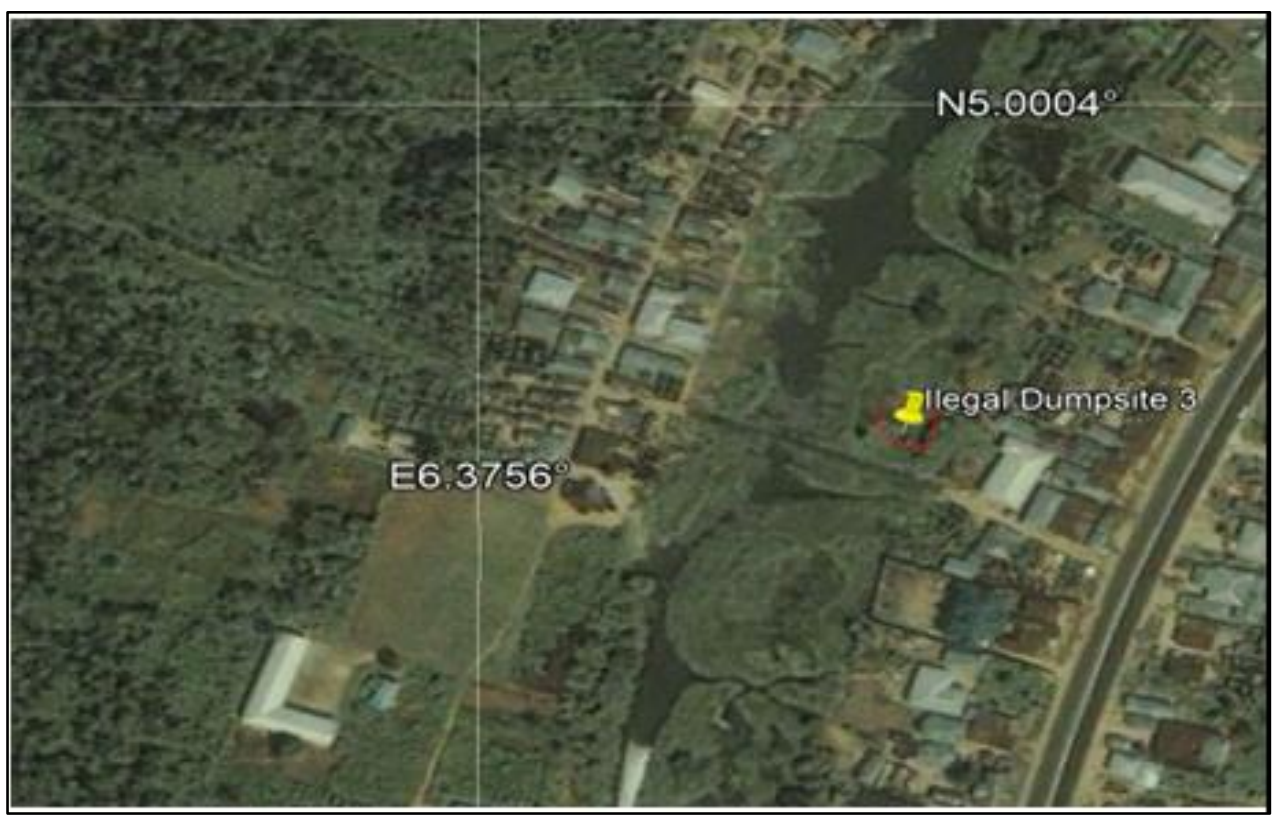

Figure-9a. Google map of 1990 in Akenfa Market Showing illegal Dumpsite 3 not present

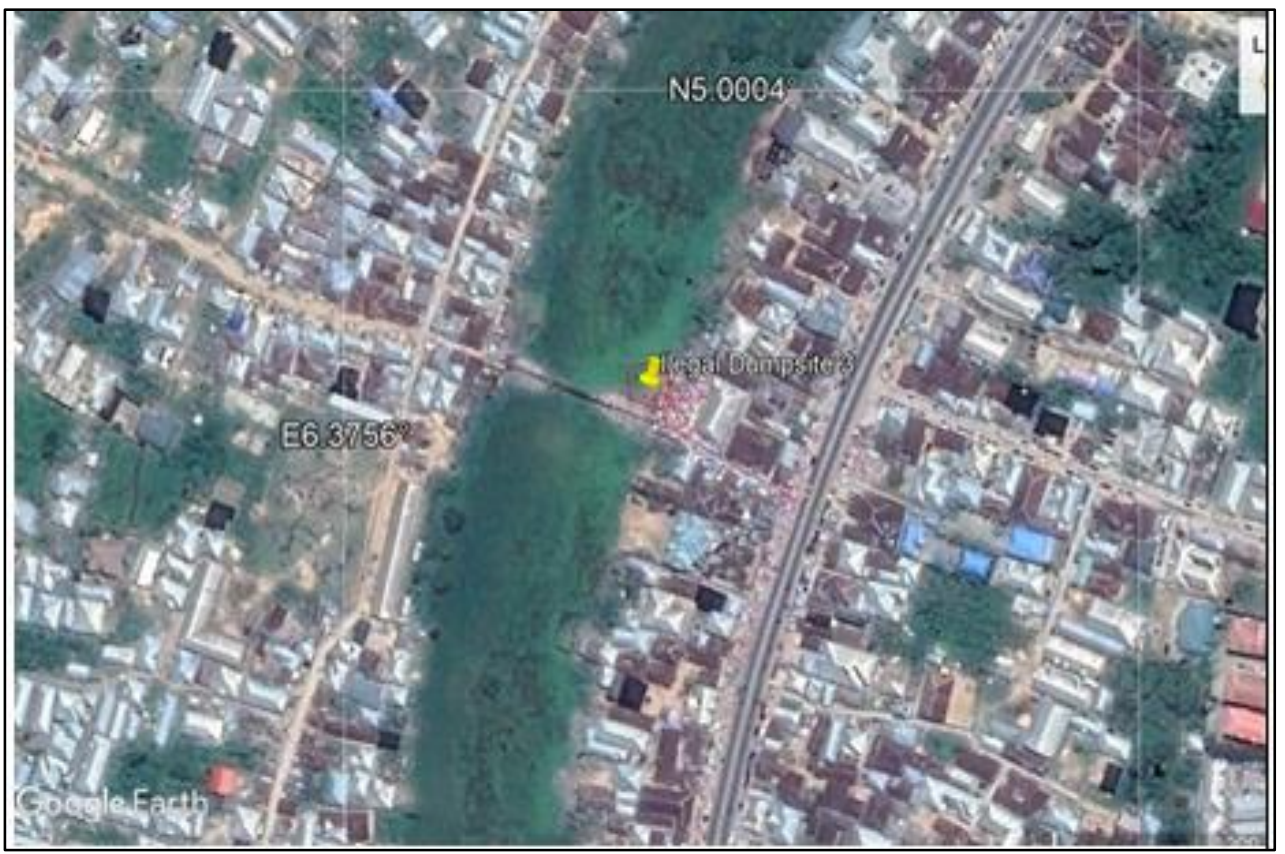

Figure-9b. Google map of 2015 in Akenfa Market showing illegal dumpsite 3 present

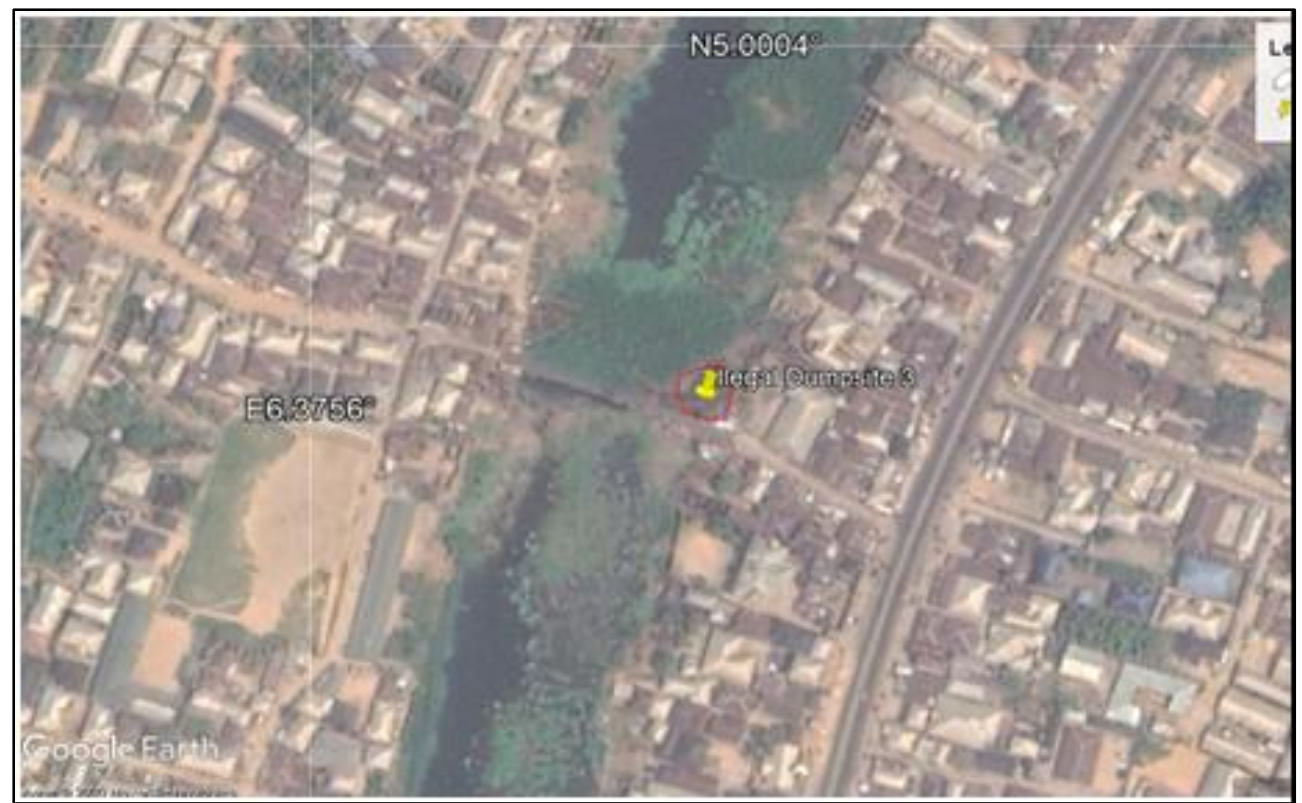

Figure-9c. Google map of 2020 in Akenfa Market, showing illegal dumpsite 3 present 
Sumerianz Journal of Scientific Research

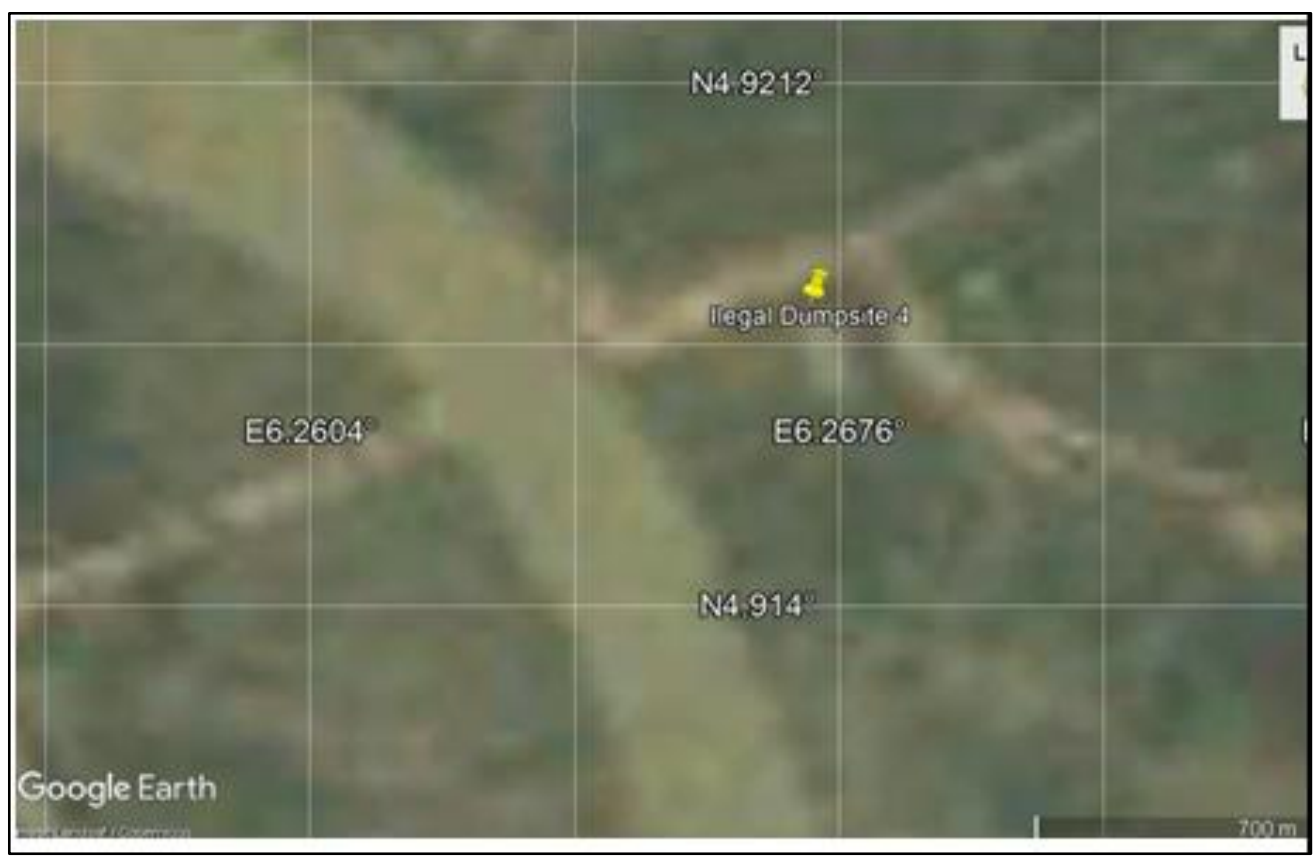

Figure-10a. Google map of 1990 in Swail Market Showing illegal Dumpsite 4 not present

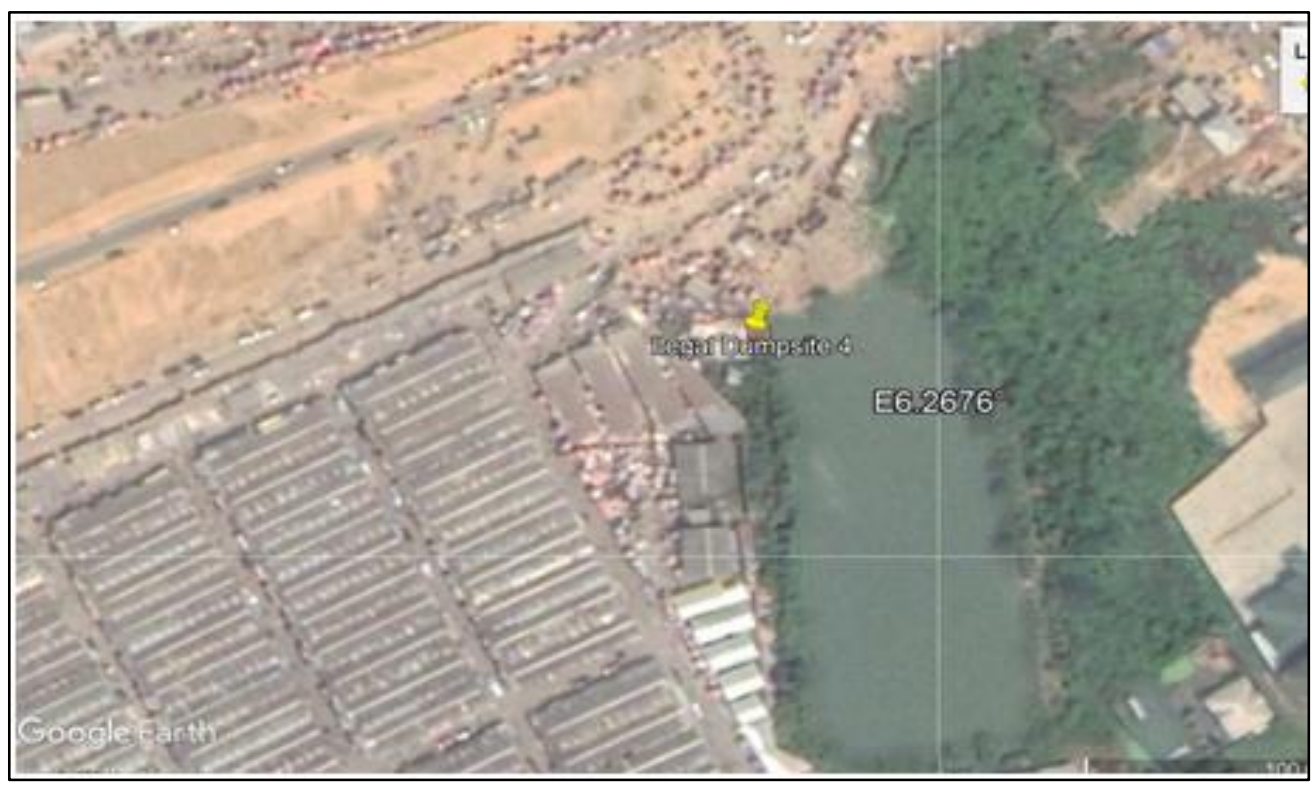

Figure-10b. Google map of 2015 in Swail Market showing illegal dumpsite 4 present

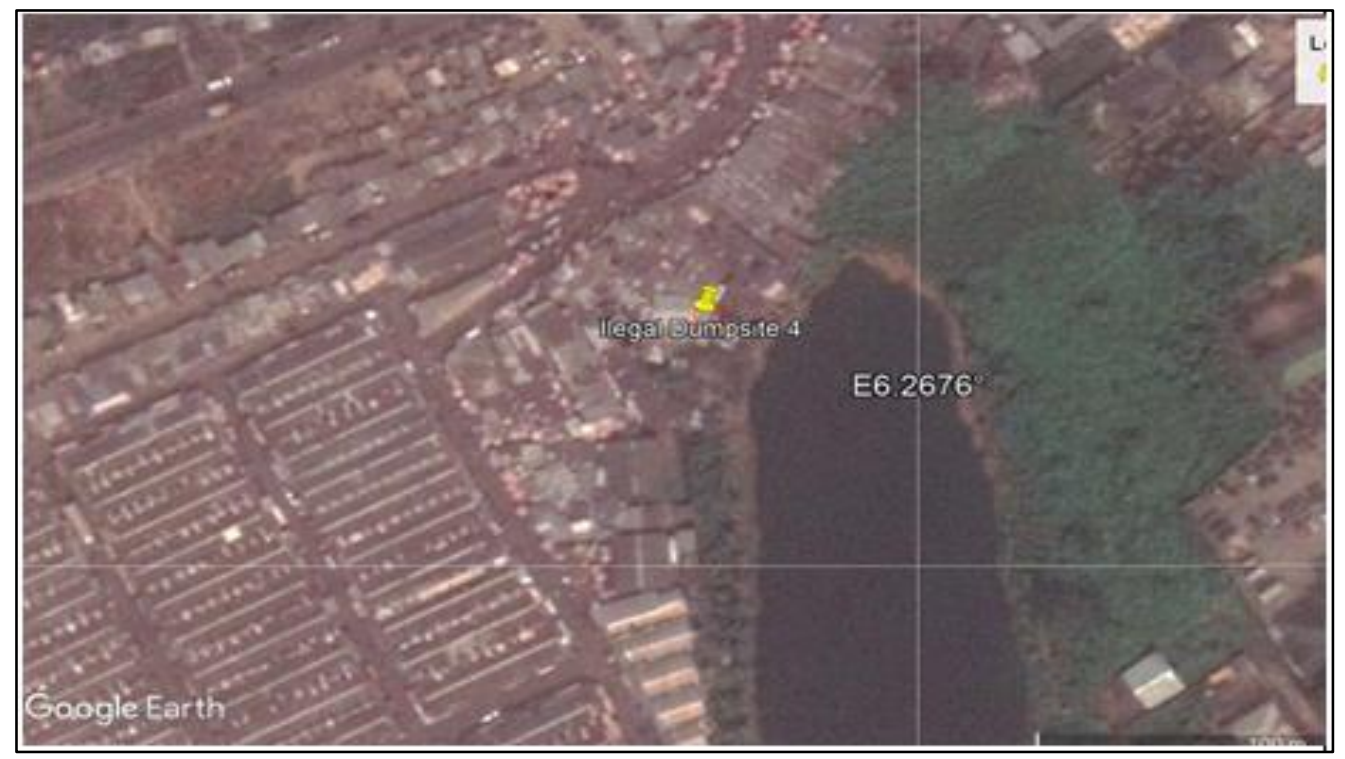

Figure-10c. Google map of 2020 in Swail Market, showing illegal dumpsite 4 present 


\section{Conclusion}

The landscape change assessment from Google Earth historical imagery and its environmental impact on landfills in Yenagoa, Bayelsa State, were studied using remote sensing and geographic information systems between 1990 and 2015 and 2020. (GIS). The typical land use was assessed using remote sensing imagery combined with GIS. The result shows an increase in built-up area of $19 \%$ from 1990 to 2015, and bare land by $7 \%$ from 1990 to 2015 and 8\% from 2015 to 2020, as shown in Figures 8b, 8c, and 9b, 9c, 10b, and 10c from various historical Google images, implying population growth due to migration and industrial activities in the area. It has also been discovered that all illegal landfills are located along the market environment, which is too close to the Epie creek. Furthermore, the pollution load index and the contamination factor results indicate the presence of heavy metals in the area. As a result, it is suggested that urban growth be monitored in order to plan the location of various landfills in advance, and that an appropriate site survey for landfill site selection be available using GIS and remote sensing. A multicriteria analysis for the area must be created and followed. The study, which combined remote sensing and GIS, could be a useful approach to environmental planning and improvement.

\section{Acknowledgements}

My profound gratitude to Francis Omonefe for her support for the provision of software.

\section{References}

[1] Jabeen, S. Q., Mehmood, S., and Tariq, B., 2011. "Health impact caused by poor water and sanitation in district abbottabad." J. Ayub. Med. Coll. Abbottabad, vol. 23, pp. 47-50.

[2] Eteh, D., Francis, E. E., and Francis, O., 2019. "Determination of flood hazard zones using geographical information systems and remote sensing techniques: A case study in part yenagoa metropolis." Journal of Geography Environment and Earth Science International, vol. 21, pp. 1-9.

[3] Akoto, O., Ephraim, J. H., and Darko, G., 2008. "Heavy metal pollution in surface soils in the vicinity of abundant railway servicing workshop in Kumasi, Ghana." Int. J. Environ. Res., vol. 2, pp. 359-364.

[4] Kamble, S. M., 2014. "Water pollution and public health issues in Kolhapur city in Maharashtra." International Journal of Scientific and Research Publications, vol. 4, pp. 1-6.

[5] Yonglong, L., Ruoshi, W., Yueqing, Z., Hongqiao, S., Pei, W., Alan, J., Rober, C. F., Mark, B., and Geoff, S., 2015. "Ecosystem health towardssustainability." Ecosystem Health and Sustainability, vol. 1, pp. 1-15.

[6] Dewan, A. and Yamaguchi, Y., 2009. "Land use and land cover change in greater Dhaka, Bangladesh: Using remote sensing to promote sustainable urbanization." Applied Geography, pp. 390-401.

[7] Masek, J., Vermote, E., Saleous, N., Wolfe, R., Hall, F., Huemmrich, K., Gao, F., Kutler, J., and Lim, T.K., 2006. "A landsat surface reflectance data set for North America, 1990-2000." Geoscience and Remote Sensing Letters, IEEE, vol. 3, pp. 68 - 72.

[8] Yang, X. and Lo, C. P., 2002. "Using a time series of satellite imagery to detect land use and land cover changes in the Atlanta, Georgia metropolitan area." International Journal of Remote Sensing, pp. 17751798. Available: $10.1080 / 01431160110075802$

[9] Angel, S., Sheppard, S., and Civco, D., 2005. The dynamics of global urban expansion. Transport and Urban Development Department.

[10] Google Earth Features, 2014. Available: http://www.google.com/earth/media/features.html

[11] Schneider, A. M. A. and Friedl, D., 2009. "A new map of global urban extent from MODIS satellite data Environ." Res. Lett., vol. 4, p. 044003.

[12] Potere, D., 2008. "Horizontal positional accuracy of google Earth's high-resolution imagery archive Sensors." vol. 8, pp. 7973-7981.

[13] Gong, P., Wang, J., Yu, L., Zhao, Y., Zhao, Y., Liang, L., and Niu, Z., 2013. "Finer resolution observation and monitoring of global land cover: first mapping results with landsat TM and ETM+ data." Int. J. Remote Sens., vol. 34, pp. 2607-2654.

[14] National Population Commission on the 2006 Census, 2007. Population and Development Review, vol. 33, pp. 206-210. Available: http://www.jstor.org/stable/25434601

[15] Available: http://www.google.com/earth/

[16] Lacatusu, R., 2000. "Appraising Levels of Soil Contamination and Pollution with Heavy Metals. European Soil Bureau-Research Report No. 4." pp. 393-403.

[17] Tomlinson, D., Wilson, J., Harris, C. R., and Jeffrey, D. W., 1980. "Problems in assessment of heavy metals in estuaries and the formation of pollution index." Helgoländer Meeresuntersuchungen, vol. 33, pp. 566575 .

[18] Zarei, I., Pourkhabbaz, A., and Bashiri, K. R., 2014. "An assessment of metal contamination risk in sediments of Hara Biosphere Reserve, southern Iran with a focus on application of pollution indicators." Environmental Monitoring and Assessment, Available: 10.1007/s10661-014-3839-x

[19] Ebenstein, A. Y., 2008. "Water pollution and digestive cancer in China. Institutions and governance programs." pp. 1-45.

[20] Ahmad, S. M., Yusafzai, F., and Bari, T., 2014. "Assessment of heavy metals in surface water of river panjkoradir lower, KPK Pakistan." J. Bio. and Env. Sci., vol. 5, pp. 144-52.

[21] Corcoran, E., Nellemann, C., and Baker, E., 2010. The central role of wastewater management in sustainable development. A rapid response assessment. United Nations Environment Programme. 
[22] Ullah, S., Javed, M. W., and Shafique, M., 2014. "An integrated approach for quality assessment of drinking water using GIS: A case study of Lower Dir." Journal of Himalayan Earth Sciences, vol. 47, pp. 163-74. 